\title{
Effects of Lactobacillus Reuteri E81 Added into Rations of Chukar Partridges (Alectoris Chukar) Fed Under Heat Stress Conditions on Fattening Performance and Meat Quality
}

\section{-Author(s)}

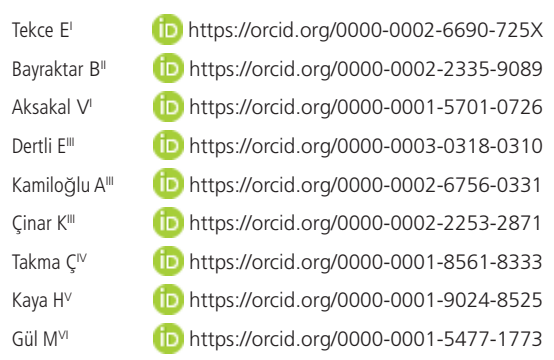

Faculty of Applied Sciences, Bayburt University Bayburt 69000, Turkey.

Faculty of Health Sciences, Bayburt University, Bayburt 69000, Turkey.

III Faculty of Engineering, Bayburt University, Bayburt 69000, Turkey.

Iv Faculty of Agriculture, Department of Animal Science, Biometry and Genetics Unit, Ege University, İzmir 35100, Turkey.

Veterinary Department, Şiran Mustafa Beyaz Vocational High School, Gümüşhane University, 29600, Şiran / Gümüșhane, Turkey.

Animal Nutrition and Nutrition Disease, Atatürk University Erzurum, Turkey.

\section{-Mail Address}

Corresponding author e-mail address Emre Tekce

Organic Agriculture Management, Faculty of Applied Sciences, Bayburt University,

Bayburt 69000, Turkey.

Phone: +90 458-333-20-33

Email: vet_emre_tekce@hotmail.com

\section{- Keywords}

Chukar partridges (Alectoris chukar), Probiotic, Performance, Meat Quality, Lactobacillus reuteri E81.

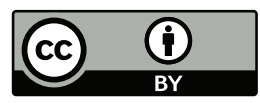

Submitted: 25/December/2019 Approved: 17/March/2020

\section{ABSTRACT}

This study investigated the effects of the addition of Lactobacillus reuteri E81 (LRE) into rations of chukar partridges (Alectoris chukar) fed under heat stress (HS) conditions on fattening performance and meat quality. This study included 256 chukar partridges aged 1 day. The study comprised an adaptation period of 7 days and a fattening period of 35 days and included 8 different groups with 32 animals in each group. Each group was further divided into four subgroups with eight animals in each subgroup. At the end of the study, the best results in terms of fattening performance in the non-HS groups were obtained in the LRE 600 ppm group and in the HS groups, SLRE 200 ppm had the best effect on average live weight and average live weight increase, whereas SLRE 400 ppm had the best effect on FCR $(p<0.05)$. The analysis of the samples collected from chukar partridges on day 21 showed that, there was no effect on the colour parameters and Thiobarbituric acid reactive substances (TBARS) level in the LRE in the HS and non- HS groups, whereas the meat pH level decreased in the SLRE 400 ppm group $(p<0.05)$. The analysis of the samples collected on day 42 showed that there was no effect on colour parameters in the HS and non-HS groups. TBARS level decreased at the dose of LRE 200 ppm in the non-HS group, and the meat pH level decreased in both HS and non-HS groups $(p<0.05)$.

\section{INTRODUCTION}

Global warming has become a major problem worldwide that adversely affects poultry yield. Poultry are homeothermic organisms that feel comfortable between $14^{\circ} \mathrm{C}$ and $27^{\circ} \mathrm{C}$ (Nardone et al., 2010, Turk et al., 2015). When the ambient temperature of a poultry house exceeds the thermoneutral levels, HS is exerted owing to the disruption of the balance between body temperature and heat emitted from the body to ensure hemostasis (Nardone et al., 2010, Ezzat et al., 2011). HS has an impact above $27^{\circ} \mathrm{C}$ and begins to exert its effect above $30^{\circ} \mathrm{C}$ (Turk et al., 2015). Endocrine system disorder and electrolyte imbalance due to HS in poultry (Liu et al., 2019, Nawab et al., 2018) have adverse effects on fattening performance and intestinal microflora (QuinteiroFilho et al., 2010; Liu et al., 2019) as well as meat quality (Lu et al., 2017). In addition, reactive oxygen species (ROS) are formed because of increased levels of mitochondria and oxidative stress due to disruption of pro-oxidant/antioxidant balance. Such ROS metabolism results in lipid peroxidation and oxidative damages in protein and DNA structure (Sarica et al., 2015).

In recent years, owing to its low fat and high protein content (603 $\mathrm{kJ} / 100 \mathrm{~g}$ and $240 \mathrm{~g}$ crude protein/ $\mathrm{kg}$ dry matter, respectively), which is considered to be good for human health, partridge meat has become 
Tekce E, Bayraktar B, Aksakal V, Dertli E, Kamiloğlu A, Çinar K, Takma Ç, Kaya H, Gül M
Effects of Lactobacillus Reuteri E81 Added into Rations of Chukar Partridges (Alectoris Chukar) Fed Under Heat Stress Conditions on Fattening Performance and Meat Quality a product of high economic value, primarily in the far east and also in many European countries (Fortin et al., 2005; Vitula et al., 2011). Cage systems are used in $90 \%$ of the partridge production in Europe and America. In some other countries, an alternative system, similar to the floor systems used for broiler chickens, is preferred with an aim to increase the production per unit area (Yıldız 2004; Alkan et al., 2008). Research on different production systems (cage system vs. floor system) has shown that, while animals housed in cage systems reach higher body weights, the best results for meat quality are achieved with the floor system (Yamak et al., 2016). It is indicated that partridge meat is juicy and of a pleasant colour and has a $\mathrm{pH}$ value ranging between 5.90-6.04 (Wen et al., 2020). To date, the growth performance of partridges has been studied relatively less than that of other avian species. Available studies report that, the crude protein and energy requirements of partridges during the starter and grower phases of the fattening period are $20 \%$ and $15 \%$, and $11.72 \mathrm{MJ} / \mathrm{kg}$ and 12.56 MJ/kg, respectively (Özek et al., 2003; Ozek, 2006). In previous research on the growth performance of partridges, animals were determined to reach a body weight of $165 \mathrm{~g}$ with a feed intake of $366.8 \mathrm{~g}$ during a period of 0-5 weeks, and the feed conversion rate of these animals was calculated as 2.23 (Gülşen et al., 2010; Khaksar et al., 2014).

For many years, antibiotics were used to maintain growth performance and animal health. However, antibiotics have been prohibited for use in animal feed because of the risk of residues and resistance to bacteria (Yörük et al., 2008; Habrun et al., 2012; Tekce \& Gül, 2016; Lajman et al., 2017). As a result, various alternative substances have been used to protect animal health and increase yield. One of these alternative substances is probiotics. Probiotics are considered viable microorganisms that improve intestinal microflora and have positive effects on poultry health when taken at appropriate doses (Sivamaruthi et al., 2019). It has been reported that probiotics improve fattening performance, (Mountzouris et al., 2007; Shim et al., 2010; Al-Fataftah \& Abdelqader, 2014; Incharoen et al., 2019), decrease mortality (Mountzouris et al., 2007), increase activity of digestive enzymes (Wang $\& \mathrm{Gu}, 2010)$, improve intestinal health by preserving intestinal microflora and synthesise vitamins (Awad et al., 2009; Alkhalf et al., 2010; Mountzouris et al., 2010; Sen et al., 2012), have antimicrobial properties (Pringsulaka et al., 2015, de Melo Pereira et al., 2018), maintain intestinal histology, decrease
$\mathrm{pH}$ and release bacteriocins (Alkhalf et al., 2010; AlFataftah \& Abdelqader, 2014; Incharoen et al., 2019), exert anticholesterol, antiobesity and antidiabetic effects (Nguyen et al., 2007; Costabile et al., 2017; Hu et al., 2017; de Melo Pereira et al., 2018), exert antiparasitic effects (Giannenas et al., 2012), protect against cardiovascular risks (Costabile et al., 2017), reduce stress (Zhang et al., 2016), decrease foodborne bacteria (Khan \& Naz, 2013) and exert positive effects on meat quality (Pelicano et al., 2003, Wattanachant et al., 2004).

The present study investigated the effects of Lactobacillus reuteri E81 (LRE) added at various doses $(200,400$ and 600 ppm) into rations of chukar partridges (Alectoris chukar) fed under HS conditions on fattening performance (Body weight [BW], daily body weight increase [DBWG], feed utilisation ration $[F C R]$ and feed consumption [FC) and meat quality.

\section{MATERIALS AND METHODS}

\section{Animals, Experimental Design and Feed}

The study included 256 male chukar partridges aged 1 day. The study comprised an adaptation period of 7 days and a fattening period of 35 days and was performed in $100 \times 50 \times 100 \mathrm{~cm}$ cages in the Poultry Unit of Bayburt University, Food, Agriculture and Livestock Application and Research Center. From day 7 of the study, live weights of animals were equally measured, and the animals were divided into eight groups (C, LRE 250, LRE 400, LRE 600, SC, SLRE 200, SLRE 400 and SLRE 600) with 32 animals in each group. From day 7 , the animals were divided into two groups as non-stress group $\left(25^{\circ} \mathrm{C} ; \mathrm{C}, \mathrm{LRE}\right.$ 250, LRE 400 and LRE 600) and HS group $\left(37^{\circ} \mathrm{C}\right.$; SC, SLRE 200, SLRE 400 and SLRE 600) for 35 days. Each group was further divided into four subgroups with eight animals in each subgroup. The feeds used in the study were prepared by a private company operating in Erzurum, and their nutrient contents are shown in Table 1. After the feeds in front of the animals were weighed at the same time each day (18:00-19:00) and the basal diet feeds were measured, the probiotics were added at appropriate doses into the feeds and given to the groups other than the control groups. The probiotics used in the study were produced in Bayburt University Faculty of Engineering, Food Department Laboratories (4 $\times 10^{10} \mathrm{CFU} / \mathrm{g}$ ). Nutrient analyses of the feeds used throughout the study were performed in accordance with the methods stated in AOAC (AOAC, 2005). 
Tekce E, Bayraktar B, Aksakal V, Dertli E, Kamiloğlu A, Çinar K, Takma Ç, Kaya H, Gül M

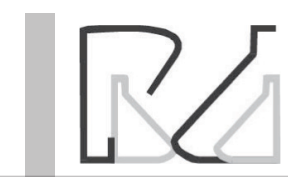

Table 1 - Basal diet ration nutrient content and analysis (g/kg).

\begin{tabular}{lccc}
\hline Raw Material & $\begin{array}{c}\text { Starter } \\
(0-14 \mathrm{~d})\end{array}$ & $\begin{array}{c}\text { Grower } \\
(14-28 \mathrm{~d})\end{array}$ & $\begin{array}{c}\text { Finisher } \\
(28-42 \mathrm{~d})\end{array}$ \\
\hline Maize & 52.70 & 54.60 & 58.12 \\
Maize gluten feed & 15.21 & 21.20 & 26.14 \\
\hline Soybean residue & 26.35 & 18.90 & 10.65 \\
Di-calcium phosphate & 1.95 & 1.70 & 1.60 \\
Calcium carbonate & 1.18 & 1.10 & 1.04 \\
Sodium chloride & 0.31 & 0.31 & 0.31 \\
Sodium bicarbonate & 0.20 & 0.20 & 0.20 \\
Salt & 0.2 & 0.2 & 0.2 \\
Methionine & 0.50 & 0.50 & 0.44 \\
Lysine & 1.20 & 1.10 & 1.10 \\
Vitamin-mineral premix & 0.20 & 0.20 & 0.20 \\
\hline ME (kcal/ kg) & 3100 & 3150 & 3225 \\
Crude protein (\%) & 24 & 22 & 20 \\
\hline Crude oil (\%) & 2.61 & 2.30 & 2.50 \\
Ash (\%) & 5.19 & 4.63 & 3.85 \\
Moisture (\%) & 13.20 & 13.20 & 13.20 \\
\hline
\end{tabular}

The vitamin-mineral premix provided the following (per $\mathrm{kg}$ of diet): vitamin A, 6000 IU; vitamin D3, $1000 \mathrm{IU}$; vitamin E, $15 \mathrm{mg} / \mathrm{kg}$; vitamin $\mathrm{K} 2 \mathrm{mg} / \mathrm{kg}$; vitamin B1, $3 \mathrm{mg}$; vitamin B2, 4 mg; vitamin B6, 4 mg; vitamin B10, 0.03 mg; calcium -D-pantothenate, $15 \mathrm{mg}$; folic acid, $1 \mathrm{mg}$; niacin, 25 mg; D-biotin, $0.115 \mathrm{mg}$; Mg $80 \mathrm{mg} / \mathrm{kg} ; \mathrm{l}, 0,15 \mathrm{mg} /$ $\mathrm{kg} ; \mathrm{Co}, 0.2 \mathrm{mg} / \mathrm{kg} ; \mathrm{Cu}, 5 \mathrm{mg} / \mathrm{kg} ; \mathrm{Fe}, 60 \mathrm{mg} / \mathrm{kg} ; \mathrm{Se}, 1 \mathrm{mg} / \mathrm{kg} ; \mathrm{Zn}, 60 \mathrm{mg} / \mathrm{kg}$.

\section{Temperature, humidity and illumination of the poultry house}

The overall temperature of the poultry house was kept constant at $32^{\circ} \mathrm{C}-33^{\circ} \mathrm{C}$ for the first 2 days and at $27^{\circ} \mathrm{C}-28^{\circ} \mathrm{C}$ for the next 5 days, and then, the stress groups were subjected to $\mathrm{HS}$ at $37^{\circ} \mathrm{C}$ and $75 \%-85 \%$ humidity, whereas the other groups were subjected to a temperature at $25^{\circ} \mathrm{C}$ and $55 \%-60 \%$ humidity. Throughout the study, all groups were subjected to illumination $(60 \mathrm{~W})$ for 24 hours. Chukar partridges were given fresh drinking water ad libitum. The general temperature in the pen was kept constant at $28-32^{\circ} \mathrm{C}$ for the first 2 days and at $27-28^{\circ} \mathrm{C}$ for the next 5 days of the experiment. Trial groups are divided into stress and stress-free starting from 7 days. Heating of the cluster was provided by means of $36 \pm 1 \mathrm{C}$ sensitive thermostat appliances (TURKEY) connected to the central heating system for 7-42 days. Temperature and humidity values were measured with daily digital temperature-humidity meter (TFA Dostmann, Germany) thermometers placed at 4 different points of the coop to control the temperature in the coop. The room temperature of stress-free groups is designed to be $22^{\circ} \mathrm{C}$.

\section{Performance parameters}

Body weight (BW), body weight gain (BWG) and feed intake (FI) were measured at 7, 14, 21, 28, 35 and 42 days of age. $\mathrm{Fl}$ of chukar partridges were recorded
Effects of Lactobacillus Reuteri E81 Added into Rations of Chukar Partridges (Alectoris Chukar) Fed Under Heat Stress Conditions on Fattening Performance and Meat Quality

on subgroups basis, the uneaten feed was discarded and fresh feed replaced in feeders at the end of each day. The BW of the chukar partridges were recorded by weighing them weekly on digital precision scales with a sensitivity of $0.001 \mathrm{gr}$. Feed conversion ratio (FCR) was calculated as total Fl (g) / total BWG (g). Mortality was recorded when it occurred.

\section{Quality and Antioxidant Properties of Meat}

At the end of the experiment, the above-mentioned parameters were applied for the cervical dislocation method of breast meat samples taken on the $21^{\text {st }}$ and $42^{\text {nd }}$ days from 3 randomly selected animals of each group, making 12 pieces and in total 96 male chukar partridges (Alectoris chukar). The analysis was conducted in the Bayburt University Food Engineering Department's Meat Technology Laboratory.

\section{pH Determination}

The $\mathrm{pH}$ determination of the breast meat was performed by using samples weighing $10 \mathrm{~g}$ that were mixed with $100 \mathrm{ml}$ of distilled water and subjected to homogenization using ultra-turrax (IKA Werk7 T 25, Germany) for $1 \mathrm{~min}$. The $\mathrm{pH}$ of the homogenate was measured with a pH meter (Mettler-Toledo AG, 8603 Schwerzenbach, Switzerland).

\section{TBARS (Thiobarbituric Acid Reactive Substan- ces) Value Determination}

TBARS analysis was performed to determine the lipid peroxidation degree of the samples. The determination of TBARS value of the samples was performed by using the method given by Lemon (Lemon, 1975). The calculation of TBARS values was performed by using the absorbance values obtained with the help of the formula below and the results were given in mg MDA (Malondialdehyde) / kg.

TBARS $=(($ absorbance $/ \mathrm{k}(0.06) \times 2 / 1000) \times 6.8) \times$ 1000 / sample weight

\section{Color Values Determination}

The determination of Color values of samples ( $\mathrm{L}$ $*, a *, b *)$ were performed by using Chroma Meter (CR-400 Konika Minolta, Japan) colorimeter. Color measurements were evaluated according to the criteria set by the International Commission on Lighting (Commission Internationale De L'Eclairage). According to these criteria; $L * ; L^{*}=0$, black; $L *=100$ white (darkness / lightness); $a^{*} ;+a^{*}=$ red, $-a{ }^{*}=$ green and $b * ;+b *=$ yellow, $b *=$ blue indicates the intensity of the above-mentioned colors. 
Tekce E, Bayraktar B, Aksakal V, Dertli E, Kamiloğlu A, Çinar K, Takma Ç, Kaya H, Gül M

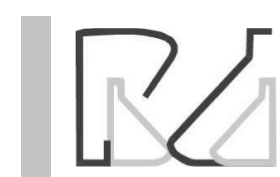

Effects of Lactobacillus Reuteri E81 Added into Rations of Chukar Partridges (Alectoris Chukar) Fed Under Heat Stress Conditions on Fattening Performance and Meat Quality

\section{Statistical analysis}

The parameters were all normally distributed, and the data expressed by means and standard errors. The statistical analyses of the diet and temperature effects on performance parameters, internal organ weights and meat quality were performed using the general linear model (GLM) that was given below.

$$
Y_{i j k}=\mu+D_{i}+T_{j}+(D * T)_{i j}+e_{i j k},
$$

where: $Y_{\text {iik }}=$ an observation, $\mu=$ overall mean, $D_{i}=$ Diet effect, $T_{i}=$ Temperature effect, $(D * T)_{i j}=$ the interaction effect and $\mathrm{e}_{\mathrm{ijk}}=$ experimental error.

The Duncan's multiple comparison test was performed for group means with a significance level of 0.05 by IBM SPSS Statistics V25.

\section{RESULTS}

The effects of LRE added at various doses (200, 400 and 600 ppm) into rations of chukar partridges fed under HS conditions on fattening performance parameters (BW, DBWG, feed consumption and feed utilisation ratio [FCR]) are shown in Table 2 . The analysis of the data obtained at the end of the study showed that the best results in terms of fattening performance in the non-stress groups $\left(25^{\circ} \mathrm{C}\right)$ were obtained in the LRE 600 ppm group $(p<0.05)$. In the HS groups $\left(37^{\circ} \mathrm{C}\right)$, the SLRE 200 ppm and SLRE 400 ppm groups had the best results in terms of BW and DBWG and FCR, respectively $(p<0.05)$.

The effects of the LRE on colour parameters $\left(L^{*}, a^{*}\right.$ and $\left.b^{*}\right)$ and TBARS and $\mathrm{pH}$ levels of chukar partridges'

Table 2 - Effect of LRE fattening performance added to the chukar partridges Ration Fed under stress.

\begin{tabular}{|c|c|c|c|c|c|c|c|c|c|}
\hline & & \multicolumn{2}{|c|}{ BW (g) } & \multicolumn{2}{|c|}{ DBWG (g) } & \multicolumn{2}{|c|}{$\mathrm{FC}(\mathrm{g})$} & \multicolumn{2}{|c|}{ FCR $(g / g)$} \\
\hline & $\mathrm{N}$ & $25^{\circ} \mathrm{C}$ & $37^{\circ} \mathrm{C}$ & $25^{\circ} \mathrm{C}$ & $37^{\circ} \mathrm{C}$ & $25^{\circ} \mathrm{C}$ & $37^{\circ} \mathrm{C}$ & $25^{\circ} \mathrm{C}$ & $37^{\circ} \mathrm{C}$ \\
\hline Control & 64 & $166.18^{b}$ & $142.39^{b}$ & $4.75^{b}$ & $4.07^{b}$ & $18.37^{a}$ & $25.29^{a}$ & $3.87^{a}$ & $6.22^{\mathrm{a}}$ \\
\hline LRE $200 \mathrm{mg} / \mathrm{kg}$ & 64 & $165.09^{b}$ & $157.61^{a}$ & $4.72^{b}$ & $4.50^{\mathrm{a}}$ & $14.86^{c}$ & $19.49^{b}$ & $3.15^{c}$ & $4.33^{b}$ \\
\hline LRE 400 mg/kg & 64 & $144.29^{c}$ & $141.25^{b}$ & $4.12^{c}$ & $4.04^{b}$ & $14.65^{b}$ & $12.07^{d}$ & $3.55^{b}$ & $2.99^{d}$ \\
\hline \multirow[t]{2}{*}{ LRE $600 \mathrm{mg} / \mathrm{kg}$} & 64 & $177.46^{\mathrm{a}}$ & $145.61^{b}$ & $5.07^{a}$ & $4.16^{b}$ & $12.83^{d}$ & $13.46^{c}$ & $2.53^{d}$ & $3.24^{c}$ \\
\hline & SEM & \multicolumn{2}{|c|}{1.57} & \multicolumn{2}{|c|}{0.05} & \multicolumn{2}{|c|}{0.11} & \multicolumn{2}{|c|}{0.05} \\
\hline \multicolumn{10}{|c|}{ Main effect means diet } \\
\hline Control & & \multicolumn{2}{|c|}{$154.27^{b}$} & \multicolumn{2}{|c|}{$4.40^{\mathrm{b}}$} & \multicolumn{2}{|c|}{$21.83^{a}$} & \multicolumn{2}{|c|}{$5.04^{a}$} \\
\hline LRE $200 \mathrm{mg} / \mathrm{kg}$ & & \multicolumn{2}{|c|}{$161.35^{\mathrm{a}}$} & \multicolumn{2}{|c|}{$4.61^{\mathrm{a}}$} & \multicolumn{2}{|c|}{$17.17^{b}$} & \multicolumn{2}{|c|}{$3.74^{b}$} \\
\hline LRE 400 mg/kg & & \multicolumn{2}{|c|}{$142.76^{c}$} & \multicolumn{2}{|c|}{$4.07 c$} & \multicolumn{2}{|c|}{$13.36^{c}$} & \multicolumn{2}{|c|}{$3.27^{c}$} \\
\hline \multirow{2}{*}{ LRE $600 \mathrm{mg} / \mathrm{kg}$} & & \multicolumn{2}{|c|}{$161.53^{\mathrm{a}}$} & \multicolumn{2}{|c|}{$4.61^{a}$} & \multicolumn{2}{|c|}{$13.14^{c}$} & \multicolumn{2}{|c|}{$2.88^{d}$} \\
\hline & SEM & \multicolumn{2}{|c|}{1.11} & \multicolumn{2}{|c|}{0.03} & \multicolumn{2}{|c|}{0.08} & \multicolumn{2}{|c|}{0.04} \\
\hline \multicolumn{10}{|l|}{ Temperature } \\
\hline $25^{\circ} \mathrm{C}$ & & \multicolumn{2}{|c|}{163.25} & \multicolumn{2}{|c|}{4.66} & & & & \\
\hline $37^{\circ} \mathrm{C}$ & & & & & & & & & \\
\hline & SEM & & & & & & & & \\
\hline Source of variation & & & & & & & & & \\
\hline Diet & & & & & & & & & \\
\hline Temperature & & & & & & & & & \\
\hline Temperature $\times$ Diet & & & & & & & & & \\
\hline
\end{tabular}

Body weight (BW), body weight gain (BWG) and feed intake (FI), Feed conversion ratio (FCR). Means within a column showing different superscripts are significantly different $(p<0.05)$ : least significance difference test was applied to compare means. ${ }^{*}$ Significant at 0.05 level, ${ }^{* *}$ Significant at 0.01 level, $S E M=$ standard error of the mean.

meat from the analysis of data obtained at the end of the study are shown in Tables 3 and 4 . The analysis of the samples collected on day 21 showed that the LRE had no effect on the $L^{*}, a^{*}$ and $\mathrm{pH}$ levels in the non-stress groups $\left(25^{\circ} \mathrm{C}\right), b^{*}$ level increased in the LRE 200 ppm group and TBARS (mg malondialdehyde $[\mathrm{MDA}] / \mathrm{kg}$ ) level decreased in the probiotic groups compared with the control group $(p<0.05)$. In the $\mathrm{HS}$ groups $\left(37^{\circ} \mathrm{C}\right)$, there was no effect on the colour parameters and TBARS (mg MDA/kg) level, whereas the meat $\mathrm{pH}$ level was decreased in the SLRE $400 \mathrm{ppm}$ group $(p<0.05)$. The analysis of the samples collected on day 42 showed that there was no effect on colour parameters in the HS and non-stress groups compared with the control groups. TBARS (mg MDA/kg) level decreased at the dose of LRE 200 ppm in the nonstress groups, and the meat $\mathrm{pH}$ level decreased in both $\mathrm{HS}$ and non-stress groups $(p<0.05)$.

\section{DISCUSSION}

The present study investigated the effects of LRE added at various doses (200, 400 and 600 ppm) into rations of chukar partridges fed under HS conditions on fattening performance (BW, DBWG and FCR), meat colour parameters $\left(L^{*}, a^{*}\right.$ and $\left.b^{*}\right)$ and TBARS 
Tekce E, Bayraktar B, Aksakal V, Dertli E, Kamiloğlu A, Çinar K, Takma Ç, Kaya H, Gül M

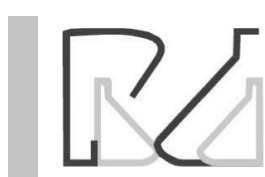

Effects of Lactobacillus Reuteri E81 Added into Rations of Chukar Partridges (Alectoris Chukar) Fed Under Heat Stress Conditions on Fattening Performance and Meat Quality

Table 3 - Meat quality and color parameters $21^{\text {st }}$ day.

\begin{tabular}{|c|c|c|c|c|c|c|c|c|c|c|c|}
\hline & & \multicolumn{2}{|c|}{$L^{*}$} & \multicolumn{2}{|c|}{$a^{*}$} & \multicolumn{2}{|c|}{$b^{*}$} & \multicolumn{2}{|c|}{ TBARS (mg MDA/kg) } & \multicolumn{2}{|r|}{$\mathrm{pH}$} \\
\hline & $\mathrm{N}$ & $25^{\circ} \mathrm{C}$ & $37^{\circ} \mathrm{C}$ & $25^{\circ} \mathrm{C}$ & $37^{\circ} \mathrm{C}$ & $25^{\circ} \mathrm{C}$ & $37^{\circ} \mathrm{C}$ & $25^{\circ} \mathrm{C}$ & $37^{\circ} \mathrm{C}$ & $25^{\circ} \mathrm{C}$ & $37^{\circ} \mathrm{C}$ \\
\hline Control & 64 & 42.83 & 39.21 & 14.49 & 14.27 & $14.28^{a}$ & 14.05 & 1.81 & 1.86 & 6.16 & $6.21^{b}$ \\
\hline LRE 200 mg/kg & 64 & 40.68 & 41.63 & 15.83 & 10.65 & $16.26^{a}$ & 13.30 & 0.89 & 0.72 & 6.32 & $6.39^{a}$ \\
\hline LRE 400 mg/kg & 64 & 38.03 & 40.05 & 13.88 & 15.11 & $10.17^{b}$ & 13.98 & 0.54 & 1.11 & 6.27 & $5.96 c$ \\
\hline \multirow[t]{2}{*}{ LRE 600 mg/kg } & 64 & 42.08 & 44.58 & 12.57 & 13.62 & $14.04^{\mathrm{a}}$ & 11.20 & 0.83 & 1.34 & 6.26 & $6.18^{b}$ \\
\hline & SEM & \multicolumn{2}{|c|}{2.59} & \multicolumn{2}{|c|}{1.69} & \multicolumn{2}{|c|}{0.88} & \multicolumn{2}{|c|}{0.27} & \multicolumn{2}{|c|}{0.05} \\
\hline \multicolumn{12}{|c|}{ Main effect means diet } \\
\hline Control & & \multicolumn{2}{|c|}{41.02} & \multicolumn{2}{|c|}{14.39} & \multicolumn{2}{|c|}{$14.18^{\mathrm{ab}}$} & \multicolumn{2}{|c|}{$1.83^{\mathrm{a}}$} & \multicolumn{2}{|c|}{$6.19^{b c}$} \\
\hline LRE 200 mg/kg & & \multicolumn{2}{|c|}{41.15} & \multicolumn{2}{|c|}{13.24} & \multicolumn{2}{|c|}{$14.78^{a}$} & \multicolumn{2}{|c|}{$0.81^{b}$} & \multicolumn{2}{|c|}{$6.35^{\mathrm{a}}$} \\
\hline LRE 400 mg/kg & & \multicolumn{2}{|c|}{39.04} & \multicolumn{2}{|c|}{14.49} & \multicolumn{2}{|c|}{$12.07^{c}$} & \multicolumn{2}{|c|}{$0.82^{b}$} & \multicolumn{2}{|c|}{$6.11^{c}$} \\
\hline \multirow[t]{2}{*}{ LRE $600 \mathrm{mg} / \mathrm{kg}$} & & \multicolumn{2}{|c|}{43.33} & \multicolumn{2}{|c|}{13.10} & \multicolumn{2}{|c|}{$12.62^{\mathrm{bc}}$} & \multicolumn{2}{|c|}{$1.09^{b}$} & \multicolumn{2}{|c|}{$6.22^{b}$} \\
\hline & SEM & & & & & & & & & & 0.03 \\
\hline Temperature & & & & & & & & & & & \\
\hline $25^{\circ} \mathrm{C}$ & & & & & & & & & & & 5.25 \\
\hline $37^{\circ} \mathrm{C}$ & & & & & & & & & & & 5.19 \\
\hline & SEM & & & & & & & & & & 0.02 \\
\hline Source of variatic & $(p-\mathrm{val}$ & & & & & & & & & & \\
\hline Diet & & & & & & & & & & & 0.00 \\
\hline Temperature & & & & & & & & & & & 0.07 \\
\hline Temperature $\times \mathrm{D}$ & & & & & & & & & & & 0.00 \\
\hline
\end{tabular}

Means within a column showing different superscripts are significantly different $(p<0.05)$ : least significance difference test was applied to compare means. ${ }^{*}$ Significant at 0.05 level, ** Significant at 0.01 level, SEM $=$ standard error of the mean.

Table 4 - Meat quality and color parameters $42^{\text {st }}$ day.

\begin{tabular}{|c|c|c|c|c|c|c|c|c|c|c|c|}
\hline & & \multicolumn{2}{|c|}{$L^{*}$} & \multicolumn{2}{|c|}{$a^{*}$} & \multicolumn{2}{|c|}{$b^{*}$} & \multicolumn{2}{|c|}{ TBARS (mg MDA/kg) } & \multicolumn{2}{|c|}{$\mathrm{pH}$} \\
\hline & $\mathrm{N}$ & $25^{\circ} \mathrm{C}$ & $37^{\circ} \mathrm{C}$ & $25^{\circ} \mathrm{C}$ & $37^{\circ} \mathrm{C}$ & $25^{\circ} \mathrm{C}$ & $37^{\circ} \mathrm{C}$ & $25^{\circ} \mathrm{C}$ & $37^{\circ} \mathrm{C}$ & $25^{\circ} \mathrm{C}$ & $37^{\circ} \mathrm{C}$ \\
\hline Control & 64 & 46.58 & 57.64 & 22.66 & 15.99 & 22.84 & 20.58 & $0.28^{\mathrm{bc}}$ & 0.30 & $6.27^{a}$ & $6.40^{\mathrm{ab}}$ \\
\hline LRE 200 mg/kg & 64 & 52.01 & 55.29 & 18.76 & 19.21 & 21.60 & 24.68 & $0.18^{c}$ & 0.36 & $6.20^{a}$ & $6.25^{c}$ \\
\hline LRE 400 mg/kg & 64 & 50.81 & 55.18 & 17.87 & 15.06 & 22.91 & 25.02 & $0.42^{\mathrm{ab}}$ & 0.29 & $6.02^{c}$ & $6.45^{\mathrm{a}}$ \\
\hline \multirow[t]{2}{*}{ LRE 600 mg/kg } & 64 & 47.13 & 48.72 & 18.69 & 16.14 & 19.38 & 22.51 & $0.50^{\mathrm{a}}$ & 0.18 & $6.10^{b}$ & $6.31^{b c}$ \\
\hline & SEM & \multicolumn{2}{|c|}{4.24} & \multicolumn{2}{|c|}{1.93} & \multicolumn{2}{|c|}{1.99} & \multicolumn{2}{|c|}{0.06} & \multicolumn{2}{|c|}{0.03} \\
\hline \multicolumn{12}{|c|}{ Main effect means diet } \\
\hline Control & & \multicolumn{2}{|c|}{52.11} & \multicolumn{2}{|c|}{19.33} & \multicolumn{2}{|c|}{21.71} & \multicolumn{2}{|c|}{0.29} & \multicolumn{2}{|c|}{$6.34^{a}$} \\
\hline LRE 200 mg/kg & & \multicolumn{2}{|c|}{53.65} & \multicolumn{2}{|c|}{18.99} & \multicolumn{2}{|c|}{23.14} & \multicolumn{2}{|c|}{0.27} & \multicolumn{2}{|c|}{$6.23^{\mathrm{b}}$} \\
\hline LRE 400 mg/kg & & \multicolumn{2}{|c|}{52.99} & \multicolumn{2}{|c|}{16.47} & \multicolumn{2}{|c|}{23.98} & \multicolumn{2}{|c|}{0.35} & \multicolumn{2}{|c|}{$6.24^{\mathrm{b}}$} \\
\hline \multirow[t]{2}{*}{ LRE 600 mg/kg } & & \multicolumn{2}{|c|}{47.93} & \multicolumn{2}{|c|}{17.41} & \multicolumn{2}{|c|}{20.94} & \multicolumn{2}{|c|}{0.34} & \multicolumn{2}{|c|}{$6.20^{\mathrm{b}}$} \\
\hline & SEM & & & & & & & & & & \\
\hline Temperature & & & & & & & & & & & \\
\hline $25^{\circ} \mathrm{C}$ & & & & & & & & & & & \\
\hline $37^{\circ} \mathrm{C}$ & & & & & & & & & & & \\
\hline & SEM & & & & & & & & & & \\
\hline Source of variatic & (p-val & & & & & & & & & & \\
\hline Diet & & & & & & & & & & & \\
\hline Temperature & & & & & & & & & & & \\
\hline Temperature $\times \mathrm{D}$ & & & & & & & & & & & \\
\hline
\end{tabular}

Means within a column showing different superscripts are significantly different $(p<0.05)$ : least significance difference test was applied to compare means. ${ }^{*}$ Significant at 0.05 level,

** Significant at 0.01 level, SEM = standard error of the mean.

(mg MDA/kg) and $\mathrm{pH}$ levels. HS has serious effects on fattening performance in poultry and results in economic losses. HS has been reported to reduce feed intake (16.4\%), BW (32.6\%) and FCR (25.6\%) in 42 days (Sohail et al., 2012, Lara and Rostagno, 2013). It has been suggested that probiotics are an alternative to antibiotics to avoid these problems and have a positive effect on intestinal microflora and histology (Ahmad, 2006, Al-Fataftah \& Abdelqader, 2014; Bitterncourt et al., 2011). The studies on poultry have reported that the addition of probiotics to their feed under HS conditions have a positive effect on fattening performance (Khonyoung \& Yamauchi, 2012; Sohail et al., 2012; Al-Fataftah \& Abdelqader, 
Tekce E, Bayraktar B, Aksakal V, Dertli E, Kamiloğlu A, Çinar K, Takma Ç, Kaya H, Gül M
Effects of Lactobacillus Reuteri E81 Added into Rations of Chukar Partridges (Alectoris Chukar) Fed Under Heat Stress Conditions on Fattening Performance and Meat Quality
2014; Incharoen et al., 2019). Contrary to these studies, some studies have reported that it has no effect (Önol et al., 2004; Asli et al., 2007; Attia et al., 2017). The analysis of data obtained at the end of the study showed that the best results in terms of fattening performance (BW, GCA, DBWG and FCR) in the non-stress groups $\left(25^{\circ} \mathrm{C}\right)$ were obtained in the LRE 600 ppm group $(p<0.05)$. In the HS groups $\left(37^{\circ} \mathrm{C}\right)$, the SLRE 200 ppm group and the SLRE 400 ppm had the best results in terms of BW and DBWG and FCR, respectively $(p<0.05)$. Although the results obtained in the present study were consistent with those of some studies (Khonyoung \& Yamauchi, 2012; Sohail et al., 2012; Al-Fataftah \& Abdelqader, 2014; Incharoen et al., 2019), some were not consistent (Önol et al., 2004; Asli et al., 2007, Attia et al., 2017). It is considered that the difference between the literature data and the current study results is because of the type and doses of probiotics used and the duration of administration.

Poultry is an important source of animal protein and accounts for $30 \%$ of global meat consumption. Because the negative effects on meat quality would affect the acceptability of meat by the consumers, the physicochemical and sensory characteristics of the meat have attracted researchers' attention (Zheng et al., 2014). There is a common view that the addition of probiotics may improve the quality of poultry meat (Al-Owaimer et al., 2014; Park et al., 2016). Some studies have shown that the addition of probiotics increased the $\mathrm{pH}$ level of poultry under HS conditions (Cramer et al., 2018). However, in some studies, HS decreased the meat $\mathrm{pH}$ level (Yalcin et al., 2005; Zhang et al., 2012). On the other hand, in some studies, the addition of probiotics has been reported to increase the meat pH level (Pelicano et al., 2003; Zheng et al., 2014; Liu et al., 2017), whereas in some other studies, it has been reported to have no effect on the pH level (Zhou et al., 2010; Park \& Kim, 2014, Park \& Kim, 2015; Bai et al., 2016a). In the present study, on day 21, there was no effect on $\mathrm{pH}$ in the non-stress groups, whereas $\mathrm{pH}$ was decreased in the SLRE $400 \mathrm{ppm}$ group in the stress groups $(p<0.05)$. However, on day 42 , the $\mathrm{pH}$ level decreased in both groups $(p<0.05)$. Although some findings of this study were consistent with those of some studies (Yalcin et al., 2005; Zhou et al., 2010; Zhang et al., 2012; Park \& Kim, 2014; Park \& Kim, 2015; Bai et al., 2016a; Lan et al., 2017), some were not consistent (Pelicano et al., 2003; Zheng et al., 2014; Liu et al., 2017; Cramer et al., 2018).
Oxidative stress, considered a significant factor in various diseases, occurs when the balance of production system of free radicals and the antioxidant defence system are disturbed. Probiotics are of benefit for animal health because they suppress oxidative stress. In addition, they are used as feed supplements to improve the performance and antioxidant capacity of animals (Bai et al., 2016b). Recently, the role of probiotics on lipid metabolism has been highlighted, which indicates that the fatty acid composition in poultry meat may be modified by probiotics (Abdulla et al., 2018). In the present study, MDA was determined as an indicator of lipid peroxidation. Some studies on poultry have determined that the addition of probiotics has decreased TBARS and MDA levels (Kazemi et al., 2019, Wu et al., 2019). In another study, the animals were subjected to HS and probiotics, and HS increased TBARS level, whereas in the stress group administered with probiotics, TBARS level decreased (Cramer et al., 2018). In the present study, on day 21, TBARS (mg MDA $/ \mathrm{kg}$ ) level decreased in the non-stress probiotic groups $(p<0.05)$. However, there was no effect on TBARS (mg MDA/kg) level in the stress groups. On day 42, there was no effect on TBARS (mg MDA/kg) level in the stress groups, whereas it decreased in the nonstress LRE 200 ppm group $(p<0.05)$. Based on these results and the literature, it may be suggested that HS causes oxidative damage in tissues and increases MDA level; however, the probiotics when added at a certain level improve this condition.

The majority of the consumers consider meat colour as the main criterion when buying meat (Karaoglu et al., 2004, Bai et al., 2016b). The probiotic supplementation to poultry feeds decreased the $L^{*}$ value in some studies (Pelicano et al., 2003, Chen et al., 2013); however, in other studies, it increased the colour parameters of meat $\left(L^{*}, a^{*}\right.$ and $\left.b^{*}\right)$ (Zheng et al., 2014) or had no effect on the colour parameters $\left(L^{*}, a^{*}\right.$ and $\left.b^{*}\right)$ (Park \& Kim, 2014, Park \& Kim, 2015, Bai et al., 2016a, Kim et al., 2016, Lan et al., 2017). In another study on poultry, HS and probiotic supplementation did not affect colour parameters (Cramer et al., 2018). In the present study, there was no effect on $L^{*}$ or $a^{*}$ in the non-stress groups, whereas the $b^{*}$ level was increased in the LRE 200 ppm group $(p<0.05)$. There was no effect on colour parameters on day 21 in the stress groups and on day 42 in both groups. It is considered that these differences between the literature data in $\mathrm{pH}$, TBARS and colour parameter analyses to determine the meat quality are because of the type and doses of probiotics used and the duration of administration. 
Tekce E, Bayraktar B, Aksakal V, Dertli E, Kamiloğlu A, Çinar K, Takma Ç, Kaya H, Gül M
Effects of Lactobacillus Reuteri E81 Added into Rations of Chukar Partridges (Alectoris Chukar) Fed Under Heat Stress Conditions on Fattening Performance and Meat Quality

\section{CONCLUSION}

The LRE mixture added at various doses into rations of chukar partridges fed under HS conditions had a positive effect on the fattening performance and meat quality on days 21 and 42. The addition of LRE 200 ppm had a positive effect on the fattening performance in the stress groups, and it increased the $b$ * level on day 21, but had no effect on it on day 42. Moreover, it had a reducing effect on TBARS and $\mathrm{pH}$ levels on days 21 and 42. Dietary probiotic supplementation was determined to improve the growth performance of chukar partridges raised under HS conditions. There is a need for further research on LRE, which has the potential to increase product quantity and quality by reducing the stress on poultry.

\section{AKNOWLEDGMENT}

This study was conducted pursuant to the approval (dated 12.11.2019 and numbered 2019/15) of the Local Ethics Board for Animal Experiments of Directorate of Veterinary Control Center Research Institute. This study was funded and supported by the scientific research projects commission of Bayburt University, Bayburt, Turkey (Project code: 2018/02-69001-02). The authors declare that they have no conflict of interest.

\section{REFERENCES}

Abdulla N, Sabow A, Foo H, Loh T, Zamri A. Growth performance, fatty acid profile and lipid oxidative $s$ ability of breast muscle in chickens fed probiotics and antibiotics or their mixture. South African Journal of Animal Science 2018;48(6):1082-1092.

Ahmad I. Effect of probiotics on broilers performance. International Journal of Poultry Science 2006;5:593-597.

Al-Fataftah AR, Abdelqader A. Effects of dietary bacillus subtilis on heatstressed broilers performance, intestinal morphology and microflora composition. Animal Feed Science and Technology 2014;198:279-285.

Alkan S, Karabağ K, Galiç A, Balcıoğlu MS. The effects of male and female ratio on hatchability traits of Partridges (A. Chukar). Journal of Lalahan Livestock Research Enstitüte 2008;48:45-50.

Al-Owaimer AN, Suliman GM, Alyemni AH, Abudabos AM. Effect of different probiotics on breast quality characteristics of broilers under salmonella challenge. Italian Journal of Animal Science 2014;13:3189.

Alkhalf A, Alhaj M, Al-Homidan I. Influence of probiotic supplementation on blood parameters and growth performance in broiler chickens. Saudi Journal of Biological Sciences 2010;17:219-225.

AOAC. Official methods of analysis of AOAC international. $18^{\text {th }}$ ed. Rockville: Association of Official Analytical Chemists; 2005.

Asli MM, Hosseini SA, Lotfollahian H, Shariatmadari F. Effect of probiotics, yeast, vitamin e and vitamin c supplements on performance and immune response of laying hen during high environmental temperature. International Journal of Poultry Science 2007;6:895-900.
Attia YA, Al-Harthi MA, El-Shafey AS, Rehab YA, Kim WK. Enhancing tolerance of broiler chickens to heat stress by supplementation with vitamin e, vitamin c and/or probiotics. Annals of Animal Science 2017; 17:1155-1169.

Awad W, Ghareeb K, Abdel-Raheem S, Böhm J. Effects of dietary inclusion of probiotic and synbiotic on growth performance, organ weights, and intestinal histomorphology of broiler chickens. Poultry Science 2009;88:49-56.

Bai K, Huang Q, Zhang J, He J, Zhang L, Wang, T. Supplemental effects of probiotic bacillus subtilis fmbj on growth performance, antioxidant capacity, and meat quality of broiler chickens. Poultry Science 2016a;96:74-82.

Bai WK, Zhang FJ, He TJ, Su PW, Ying XZ, Zhang LL, et al. Dietary probiotic bacillus subtilis strain fmbj increases antioxidant capacity and oxidative stability of chicken breast meat during storage. PloS One 2016b;11:e0167339.

Bitterncourt LC, Silva CCD, Garcia PDSR, Donato DCZ, Albuquerque RD, Araújo LF. Influence of a probiotic on broiler performance. Revista Brasileira de Zootecnia 2011;40:2739-2743.

Blajman JE, Olivero C, Fusari ML, Zimmermann JA, Rossler E, Berisvil AP, et al. Impact of lyophilized lactobacillus salivarius dspv $001 \mathrm{p}$ administration on growth performance, microbial translocation, and gastrointestinal microbiota of broilers reared under low ambient temperature. Research in Veterinary Science 2017;114:388-394.

Chen W, Wang J, Yan L, Huang Y. Evaluation of probiotics in diets with different nutrient densities on growth performance, blood characteristics, relative organ weight and breast meat characteristics in broilers. British Poultry Science 2013;54:635-641.

Costabile A, Buttarazzi I, Kolida S, Quercia S, Baldini J, Swann JR, et al. An in vivo assessment of the cholesterol-lowering efficacy of lactobacillus plantarum ecgc 13110402 in normal to mildly hypercholesterolaemic adults. Plos One 2017;12:e0187964.

Cramer T, Kim H, Chao Y, Wang W, Cheng H, Kim, Y. Effects of probiotic (bacillus subtilis) supplementation on meat quality characteristics of breast muscle from broilers exposed to chronic heat stress. Poultry Science 2018;97:3358-3368.

De Melo Pereira GV, De Oliveira Coelho B, Júnior AIM, Thomaz-Soccol V, Soccol CR. How to select a probiotic? A review and update of methods and criteria. Biotechnology Advances 2018;36:2060-2076.

Ezzat W, Shoeib MS, Mousa SMM, Bealish AMA, İbrahiem ZA. Impact of betaine, vitamin $C$ and folic acid supplementations to the diet on productive and reproductive performance of Matrouh poultry strain under Egyptian summer condition. Egyptian Poultry Science Journal 2011;31:521-537

Fortin A, Robertson W, Tong A. The eating quality of Canadian pork and its relationship with intramuscular fat. Meat Science 2005;69:297-305

Giannenas I, Papadopoulos E, Tsalie E, Triantafillou E, Henikl S, Teichmann $\mathrm{K}$, et al. Assessment of dietary supplementation with probiotics on performance, intestinal morphology and microflora of chickens infected with eimeria tenella. Veterinary Parasitology 2012;188:31-40.

Gülşen N, Umucalılar $H$, Kırıkçı K, Hayırlı A, Aktümsek A, Alaşahan S. Sunflower oil supplementation alters meat quality but not performance of growing partridges (Alectoris chukar). Journal of Animal Physiology and Animal Nutrition 2010;94:196-203.

Habrun B, Simpraga B, Kompes G, Krstulovic F. Antimicrobial resistance and serotyping of Salmonella enteric subsp. enterica isolated from poultry in Croatia. Veterinarski Arhiv 2012;4:371-381. 
Tekce E, Bayraktar B, Aksakal V, Dertli E, Kamiloğlu A, Çinar K, Takma Ç, Kaya H, Gül M

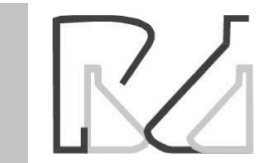

Hu YM, Zhou F, Yuan Y, Xu YC. Effects of probiotics supplement in patients with type 2 diabetes mellitus:A meta-analysis of randomized trials. Medicina Clínica 2017;148:362-370.

Incharoen T, Charoensook R, Onoda S, Tatrakoon W, Numthuam S, Pechkong T. The effects of heat-killed lactobacillus plantarum I-137 supplementation on growth performance, intestinal morphology, and immune-related gene expression in broiler chickens. Animal Feed Science and Technology 2019;257:114272.

Karaoglu M, Aksu M, Esenbuga N, Kaya M, Macit M, Durdag H. Effect of dietary probiotic on the ph and colour characteristics of carcasses, breast fillets and drumsticks of broilers. Animal Science 2004;78:253259.

Kazemi SA, Ahmadi H, Karimi Torshizi MA. Evaluating two multistrain probiotics on growth performance, intestinal morphology, lipid oxidation and ileal microflora in chickens. Journal of Animal Physiology and Animal Nutrition 2019;103(5):1399-1407.

Khan R, Naz S. The applications of probiotics in poultry production. World's Poultry Science Journal 2013;69:621-632.

Khaksar V, Veldkamp T, Hashemipour H. Effect of a prebiotic on performance of partridge. Journal of Animal Physiology and Animal Nutrition 2014;98:511-516.

Khonyoung D, Yamauchi KE. Effects of heat-killed lactobacillus plantarum I-137 on morphology of intestinal villi and epithelial cells in broiler chickens. Journal of Applied Animal Research 2012;40:140-147.

Kim H, Yan F, Hu J, Cheng H, Kim Y. Effects of probiotics feeding on meat quality of chicken breast during postmortem storage. Poultry Science 2016:95:1457-1464

Lan R, Lee S, Kim I. Effects of enterococcus faecium slb 120 on growth performance, blood parameters, relative organ weight, breast muscle meat quality, excreta microbiota shedding, and noxious gas emission in broilers. Poultry Science 2017;96:3246-3253.

Lara LJ, Rostagno MH. Impact of heat stress on poultry production. Animals 2013;3:356-369

Liu L, Ni X, Zeng D, Wang H, Jing B, Yin Z, et al. Effect of a dietary probiotic, lactobacillus johnsonii bs15, on growth performance, quality traits, antioxidant ability, and nutritional and flavour substances of chicken meat. Animal Production Science 2017;57:920-926.

Liu W, Yuan Y, Sun C, Balasubramanian B, Zhao Z, An L. Effects of dietary betaine on growth performance, digestive function, carcass traits, and meat quality in indigenous yellow-feathered broilers under long-term heat stress. Animals 2019;9:506.

Lu Z, He X, Ma B, Zhang L, Li J, Jiang Y, et al. Chronic heat stress impairs the quality of breast-muscle meat in broilers by affecting redox status and energy-substance metabolism. Journal of Agricultural and Food Chemistry 2017;65:11251-11258.

Mountzouris K, Tsirtsikos P, Kalamara E, Nitsch S, Schatzmayr G, Fegeros $K$. Evaluation of the efficacy of a probiotic containing lactobacillus, bifidobacterium, enterococcus, and pediococcus strains in promoting broiler performance and modulating cecal microflora composition and metabolic activities. Poultry Science 2007;86:309-317.

Mountzouris K, Tsitrsikos P, Palamidi I, Arvaniti A, Mohnl M, Schatzmayr G, et al. Effects of probiotic inclusion levels in broiler nutrition on growth performance, nutrient digestibility, plasma immunoglobulins, and cecal microflora composition. Poultry Science 2010;89:58-67.

Nawab A, Ibtisham F, Li G, Kieser B, Wu J, Liu W, et al. Heat stress in poultry production: mitigation strategies to overcome the future challenges facing the global poultry industry. Journal of Thermal Biology 2018;78:131-139.
Effects of Lactobacillus Reuteri E81 Added into

Rations of Chukar Partridges (Alectoris Chukar)

Fed Under Heat Stress Conditions on Fattening

Performance and Meat Quality

Nardone A, Ronchi B, Lacetera N, Ranieri MS, Bernabucci U. Effects of climate changes on animal production and sustainability of livestock systems. Livestock Science 2010;130:57-69.

Nguyen T, Kang J, Lee M. Characterization of lactobacillus plantarum ph04, a potential probiotic bacterium with cholesterol-lowering effects. International Journal of Food Microbiology 2007;113:358-361.

Önol AG, Sari M, Oğuz FK, Gülcan B, Erbaş G. The effects of dietary probiotic supplementation on some productivity and blood parameters of laying quails raised under constant heat stress. Turkish Journal of Veterinary and Animal Sciences 2004;27:1397-1402.

Özek K. The optimum protein content in high-energy starter diet for chukar partridge (Alertons chukar chukat). International Journal Poultry Science 2006:5:522-525

Özek K, Yazgan O, Bahtiyarca Y. Effects of dietary protein and energy concentrations on performance and carcase characteristics of chukar partridge (Alectoris chukar) raised in captivity. British Poultry Science 2003:44:419-426

Park J, Kim I. Supplemental effect of probiotic bacillus subtilis b2a on productivity, organ weight, intestinal salmonella microflora, and breast meat quality of growing broiler chicks. Poultry Science 2014;93:20542059 .

Park J, Kim I. The effects of the supplementation of bacillus subtilis $r x 7$ and b2a strains on the performance, blood profiles, intestinal salmonella concentration, noxious gas emission, organ weight and breast meat quality of broiler challenged with salmonella typhimurium. Journal of Animal Physiology and Animal Nutrition 2015;99:326-334.

Park YH, Hamidon F, Rajangan C, Soh KP, Gan CY, Lim TS, et al. Application of probiotics for the production of safe and high-quality poultry meat. Korean journal for food science of animal resources 2016;36:567-576.

Pelicano ERL, De Souza P, De Souza H, Oba A, Norkus E, Kodawara L, et al. Effect of different probiotics on broiler carcass and meat quality. Revista Brasileira de Ciência Avícola 2003;5:207-214

Pringsulaka O, Rueangyotchanthana K, Suwannasai N, Watanapokasin R, Amnueysit $\mathrm{P}$, Sunthornthummas $\mathrm{S}$, et al. In vitro screening of lactic acid bacteria for multi-strain probiotics. Livestock Science 2015;174:66-73.

Quinteiro-Filho WM, Ribeiro A, Ferraz-De-Paula V, Pinheiro ML, Sakai M, Sa LR, et al. Heat stress impairs performance parameters, induces intestinal injury, and decreases macrophage activity in broiler chickens. Poultry Science 2010;89:1905-1914.

Sarıca S, Özdemir D, Öztürk $H$. The effects of dietary oleuropein and organic selenium supplementation on performance and heat shock protein 70 response of brain in heat-stressed quail. Italian Journal of Animal Science 2015;14:226-232.

Sen S, Ingale S, Kim Y, Kim J, Kim K, Lohakare J, et al. Effect of supplementation of bacillus subtilis is 1-2 to broiler diets on growth performance, nutrient retention, caecal microbiology and small intestinal morphology. Research in Veterinary Science 2012;93:264268.

Shim Y, Shinde P, Choi J, Kim J, Seo D, Pak J, et al. Evaluation of multimicrobial probiotics produced by submerged liquid and solid substrate fermentation methods in broilers. Asian-Australasian Journal of Animal Sciences 2010;23:521-529.

Sivamaruthi BS, Kesika P, Chaiyasut C. Effect of probiotics supplementations on health status of athletes. International Journal of Environmental Research and Public Health 2019;16:2-14.

Sohail M, Hume M, Byrd J, Nisbet D, ljaz A, Sohail A, et al. Effect of supplementation of prebiotic mannan-oligosaccharides and probiotic mixture on growth performance of broilers subjected to chronic heat stress. Poultry Science 2012;91:2235-2240. 
Tekce E, Bayraktar B, Aksakal V, Dertli E, Kamiloğlu A, Çinar K, Takma Ç, Kaya H, Gül M

Effects of Lactobacillus Reuteri E81 Added into

Rations of Chukar Partridges (Alectoris Chukar)

Fed Under Heat Stress Conditions on Fattening

Performance and Meat Quality

Türk G, Şimşek ÜG, Çeribaşı AO, Çeribaşı S, Kaya ŞÖ, Güvenç M, et al. Effect of cinnamon (cinnamomum zeylanicum) bark oil on heat stressinduced changes in sperm production, testicular lipid peroxidation, testicular apoptosis, and androgenic receptor density in developing japanese quails. Theriogenology 2015;84:365-376.

Tekce E, Gul M. Effects of Origanum syriacum essential oil added in different levels to the diet of broilers under heat stress on performance and intestinal histology. European Poultry Science 2016;80:1-8.

Vitula F, Suchý P, Straková E, Karaskova K, Zapletal D, Kroupa L. Energy value of meat in selected species of feathered game. Acta Veterinaria Brno 2011;80:197-202.

Wang Y, Gu Q. Effect of probiotic on growth performance and digestive enzyme activity of arbor acres broilers. Research in Veterinary Science 2010:89:163-167.

Wattanachant S, Benjakul S, Ledward D. Composition, color, and texture of thai indigenous and broiler chicken muscles. Poultry Science 2004;83:123-128.

Wen Y, Liu H, Liu K, Cao H, Mao H, Dong X, et al. Analysis of the physical meat quality in partridge (Alectoris chukar) and its relationship with intramuscular fat. Poultry Science 2020;99:1225-1231.

Wu Y, Wang B, Zeng Z, Liu R, Tang L, Gong L, et al. Effects of probiotics lactobacillus plantarum 16 and paenibacillus polymyxa 10 on intestinal barrier function, antioxidative capacity, apoptosis, immune response, and biochemical parameters in broilers. Poultry Science 2019;98(10):5028-5039.

Yalcin S, Önenç A, Özkan S, Güler H, Siegel P. Meat quality of heat stressed broilers:Effects of thermal conditioning at pre-and-postnatal stages. Proceedings of the $17^{\circ}$ Europen Symposum on the Quality of Poultry Meat; 2005 May 23-26; Beekbergen: WPSA, 2005.
Yamak U, Sarica M, Boz M, Uçar A.The effect of production system (barn and free-range), slaughtering age and gender on carcass traits and meat quality of partridges (Alectoris chukar). British Poultry Science 2016;57:185-192.

Yıldız N. Chicken farming. Elazığ: Fırat Üniversity Veteriner Faculty; 2014.

Yörük MA, Laçin E, Hayirli A, Yıldız A. The effects of humate and prebiotic supplementation on laying performance, egg quality and blood parameters of Japenese quails reared in different cage densities. The Journal of the Faculty of Veterinery Medicine Universty of Yuzuncu 2008;19:15-22.

Zhang R, Zhou M, Tu Y, Zhang N, Deng $K$, Ma T, et al. Effect of oral administration of probiotics on growth performance, apparent nutrient digestibility and stress-related indicators in holstein calves. Journal of Animal Physiology and Animal Nutrition 2016;100:33-38.

Zhang Z, Jia G, Zuo J, Zhang Y, Lei J, Ren L, et al. Effects of constant and cyclic heat stress on muscle metabolism and meat quality of broiler breast fillet and thigh meat. Poultry Science 2012;91:2931-2937.

Zheng A, Luo J, Meng K, Li J, Zhang S, Li K, et al. Proteome changes underpin improved meat quality and yield of chickens (gallus gallus) fed the probiotic enterococcus faecium. BMC Genomics 2014;15:1-14

Zhou X, Wang Y, Gu Q, Li W. Effect of dietary probiotic, bacillus coagulans, on growth performance, chemical composition, and meat quality of guangxi yellow chicken. Poultry Science 2010;89:588-593. 
